\title{
Above- and below-ground production, biomass and reproductive ecology of Thalassia testudinum (turtle grass) in a subtropical coastal lagoon
}

\author{
James E. Kaldy*, Kenneth H. Dunton \\ University of Texas at Austin, Marine Science Institute, 750 Channelview Dr., Port Aransas, Texas 78373, USA
}

\begin{abstract}
Above- and below-ground growth, biomass, phenology and reproductive effort in the seagrass Thalassia testudinum were monitored monthly for $2 \mathrm{yr}$ in the Lower Laguna Madre, Texas. Annual whole plant production ( $953 \pm 136 \mathrm{~g}$ DW (dry weight) $\mathrm{m}^{-2} \mathrm{yr}^{-1}$ ) was calculated from monthly measurements of leaf and rhizome production made using marking techniques. Leaf growth exhibited a seasonal pattern; monthly production ranged from 8 to $95 \mathrm{~g} \mathrm{DW} \mathrm{m}^{-2} \mathrm{mo}^{-1}$, equivalent to $614 \pm 71 \mathrm{~g} \mathrm{DW} \mathrm{m}^{-2} \mathrm{yr}^{-1}$. Rhizome growth was seasonal, and areal below-ground production ranged between 14 and $40 \mathrm{~g} \mathrm{DW} \mathrm{m}^{-2}$ $\mathrm{mo}^{-1}$, equivalent to $339 \pm 65 \mathrm{~g} \mathrm{DW} \mathrm{m}^{-2} \mathrm{yr}^{-1}$. On an annual basis, rhizome production accounted for $35 \%$ of total plant production. Seasonal leaf and rhizome growth patterns were correlated with underwater irradiance, daylength and temperature. Total biomass ranged between 750 and $1500 \mathrm{~g} \mathrm{DW} \mathrm{m}^{-2}$, with below-ground tissues accounting for 80 to $90 \%$ of the total. There was no seasonal pattern in the belowground biomass of $T$. testudinum; variability was a result of environmental heterogeneity. Flowering was variable between years; 13 to $30 \%$ of the shoots flowered and about $15 \%$ of total above-ground biomass was allocated to reproduction. Flowering phenology was positively correlated with underwater daylength. During 1996, maximum fruit abundance ranged between 20 and 70 fruits $\mathrm{m}^{-2}$ and on average each fruit contained 2 seeds. The annual flowering event represents a substantial resource (e.g. carbon and nitrogen) investment, which may influence individual plant production. Seasonal fluctuations in environmental parameters are the primary factors controlling seagrass growth rates and production. Determination of total plant productivity must take into account seasonal patterns, reproductive costs and the large fraction of production occurring in the below-ground tissues.
\end{abstract}

KEY WORDS: Seagrass $\cdot$ Thalassia testudinum Production $\cdot$ Biomass $\cdot$ Reproduction

\section{INTRODUCTION}

In Texas, over $80 \%$ of the seagrass acreage occurs in the Laguna Madre system (Quammen \& Onuf 1993), which consistently has the highest recreational and commercial finfish landings in the State (Texas Department of Water Resources 1982). The Lower Laguna Madre (LLM), part of the hypersaline lagoon system stretching from Corpus Christi to Port Isabel, contains the largest population of Thalassia testudinum on the Texas coast. Preliminary estimates indicate that seagrass production can account for $95 \%$ of the total

\footnotetext{
- Present address: Texas A\&M University, Dept of Oceanography, College Station, Texas 77843, USA.

E-mail: kaldy@nitro.tamu.edu
}

annual gross primary productivity in LLM (Ziegler \& Benner 1999).

Seagrass species distribution in LLM is in transition, opening the Gulf Intracoastal Waterway (GIWW) increased water circulation and decreased hypersalinity, permitting the establishment of Syringodium filiforme and spread of Thalassia testudinum in LLM (Quammen \& Onuf 1993, Onuf 1996). T. testudinum cover in LLM has increased by about $32 \mathrm{~km}^{2}$ during the $40 \mathrm{yr}$ between the initial dredging of the GIWW and seagrass surveys conducted in 1988 (Quammen \& Onuf 1993). Colonization from seed coupled with rhizome expansion may account for the rapid spread of $T$. testudinum in LLM (Quammen \& Onuf 1993, Kaldy \& Dunton 1999). The shifting dominance of seagrass species may have a direct impact on the primary and sec- 
ondary productivity of the Laguna. Unfortunately, there is limited information available on the biology and ecology of $T$. testudinum in Texas (Czerny \& Dunton 1995, Lee \& Dunton 1996, 1997, Herzka \& Dunton 1997), particularly regarding the role of sexual reproduction in meadow expansion (although see Kaldy \& Dunton 1999).

The basic biology of the adult Thalassia testudinum shoot has been the primary focus of many ecological and physiological investigations with few observations of reproductive processes. Floral anatomy of $T$. testudinum has been described in detail (Orpurt \& Boral 1964, Tomlinson 1969). Flowering in Florida and Mexico has been observed and quantified (Grey \& Moffler 1978, Lewis \& Phillips 1980, Moffler et al. 1981, Phillips et al. 1981, Durako \& Moffler 1985, 1987, van Tussenbroek 1994). However, areal seed production, seedling success and reproductive effort have not been quantified for T. testudinum (except see Grey \& Moffler 1978 , Kaldy \& Dunton 1999). Seagrass reproductive ecology cannot be ignored because the formation of new genets contributes to the persistence of populations.

Thalassia testudinum is one of the most studied seagrasses; however, there are few long-term (i.e. $>1$ yr) studies of production dynamics. Below-ground production dynamics are an important aspect of seagrass ecology, because root and rhizome tissues comprise between 80 and $90 \%$ of total biomass and serve as resource storage organs (Pirc 1989, Lee \& Dunton 1996). Below-ground production is estimated to account for 10 to $30 \%$ of total production (Hillman et al. 1989), but these estimates are based on limited empirical data. Several productivity models incorporate below-ground production based on biomass allocation patterns (Short 1980, Wetzel \& Neckles 1986). Recent numerical modeling, using inverse analysis, explicitly focuses on predicting below-ground growth and plant/sediment interactions (Burd \& Eldridge 1997).

Estuarine and coastal systems are highly dynamic and infrequent sampling may not detect the impact of important short-term events (i.e. passage of fronts). Detailed, long-term monitoring allows examination of both long- and short-term patterns. Further, it permits assessment of the cumulative impacts from chronic events, e.g. recurring algal blooms, frequent dredging events

Production rates are often treated as constant through time by using annual averages that obscure seasonal patterns. Because they take into account seasonal changes, numerical summation techniques applied to high resolution data provide a powerful tool for estimating annual production. Additionally, variation between sites is rarely addressed as a result of limited spatial sampling. Site-specific differences in growth rates and biomass are generally regulated by differ- ences in environmental parameters (Dawes \& Tomasko 1988, Dixon \& Leverone 1995, Dunton 1996). We hypothesize that shallow and deep Thalassia testudinum plants will exhibit site-specific production and reproductive characteristics.

The objectives of this study were to examine longterm patterns of above- and below-ground biomass and productivity of Thalassia testudinum in LLM, Texas. Growth and biomass data were examined for seasonal patterns as well as site-specific differences related to underwater light. We also examined the flowering phenology and fruit production of $T$. testudinum in LLM. Sexual reproductive effort was quantified to determine the allocation of resources to this process. Correlation analysis was used to examine relationships between productivity and underwater irradiance, daylength, and temperature. Above- and below-ground growth rates and $\mathrm{C}: \mathrm{N}$ ratios were used to estimate T. testudinum carbon and nitrogen incorporation rates.

\section{MATERIALS AND METHODS}

Study sites. Two monotypic stands of Thalassia testudinum were monitored monthly for biomass and productivity (Fig. 1) during 1995 and 1996. The Shallow site was located on the eastern side of the GIWW at an average depth of $1.3 \mathrm{~m}$. The Deep site was located to the west of the GIWW behind dredged material placement islands at a depth of $1.7 \mathrm{~m}$ (Fig. 1). Reproductive parameters were also examined at a third site designated Stn 2 (previously described by Herzka \& Dunton 1997), which was located about $2 \mathrm{~km}$ south-west of the Shallow site with an average water depth of $1.3 \mathrm{~m}$. At all sites, $T$ testudinum was the dominant species although small stands of Halodule wrightii and Syringodium filiforme occurred locally.

Physical and chemical parameters. Continuous measurements of in situ surface and underwater photon flux density (PFD) were made using a Li-Cor datalogger (Dunton 1994) at the Deep site and at Stn 2 Data from Stn 2 were used to approximate underwater irradiance at the Shallow site because both sites had identical water depth and the same species composition. Measurements were made using LI-193SA spherical quantum sensors $(4 \pi)$ positioned at canopy height. A terrestrial sensor $(2 \pi)$ was located about $5 \mathrm{~km}$ from the study sites on a platform (Fiq. 1; Fix 1) maintained by the Conrad Blucher Institute for Surveying and Science $(\mathrm{CBI})$ at Texas A\&M-Corpus Christi. Average hourly PFD values were integrated to calculate daily PFD; daily values were then averaged over each month. Daylengyth was calculated from the hourly light data and was defined as the period when average 
hourly light values were $>1 \mu \mathrm{mol}$ photon $\mathrm{m}^{-2} \mathrm{~s}^{-1}$. Continuous measurements of water temperature collected at Fix 1 were obtained by $\mathrm{CBI}$ using an $\mathrm{H} 2 \mathrm{O}^{\text {(3) }}$ water quality multiprobe (Hydrolab, Austin, TX) that was serviced weekly. Average monthly temperature was calculated from the daily noon-time values.

Dissolved inorganic nitrogen and chlorophyll a (chl a) were measured monthly at both sites from replicate $(n=4)$ water column samples analyzed spectrophotometrically (Parsons et al. 1984). Replicate ( $\mathrm{n}=$ 4) sediment core samples were obtained quarterly at both sites using $60 \mathrm{ml}$ syringe barrels for analysis of porewater $\mathrm{NH}_{4}{ }^{+}$concentration (Parsons et al. 1984). The top $10 \mathrm{~cm}$ of sediment was homogenized and bulk porewater was extracted by centrifugation. Sediment composition at both sites was characterized following the wet method analysis of Folk (1964).

Seagrass biomass and phenology. Seagrass biomass, density and phenology (i.e. presence or absence of flowers) were determined monthly. Replicate $(n=4)$ samples were obtained using a $15 \mathrm{~cm}$ diameter corer.

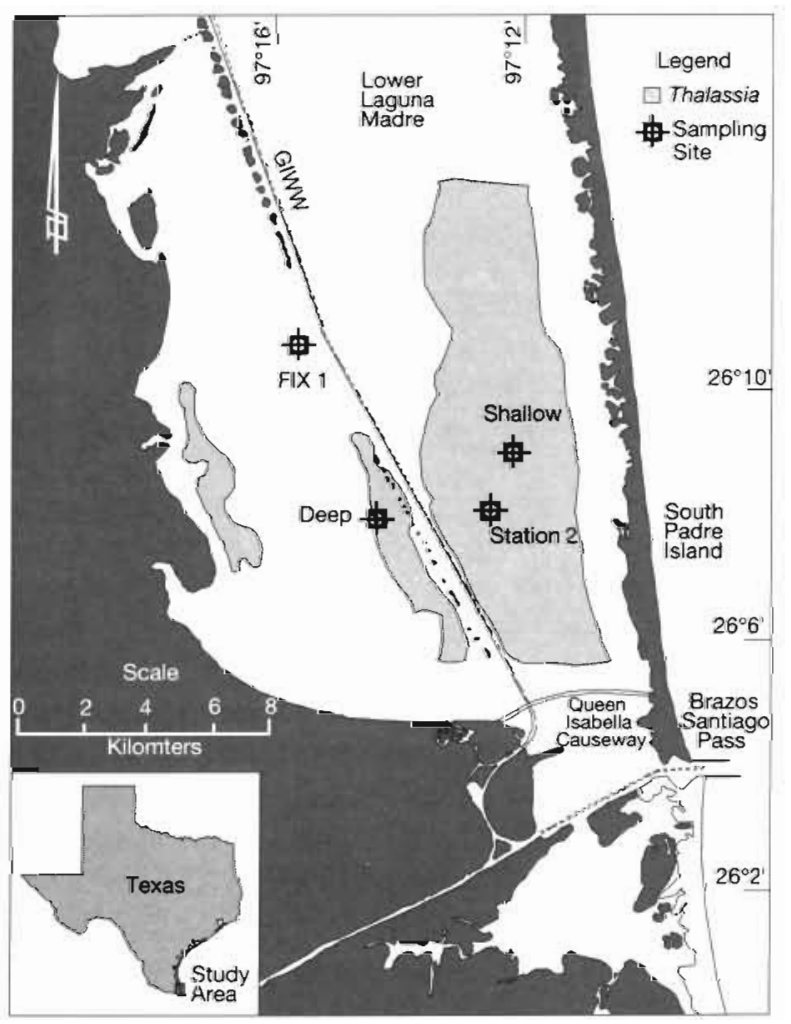

Fig. 1. Site map of the Lower Laguna Madre, showing the sampling locations for the seagrass and physical parameters. The approximate distribution of Thalassia testudinum is in light gray. Water temperature and surface photon flux density were measured at Fix 1 . Biomass, productivity and reproductive effort were measured at the Shallow and Deep sites, reproductive effort was also examined at Stn 2. (Map adapted from Brown \& Kraus 1997)
Samples were sieved to remove the sediments and plants were separated into above-and below-ground components. Above-ground components were separated into leaves (including sheath material) and floral parts, while below-ground tissues included roots and all rhizome materials. All above-ground components were counted to determine density. All dead plant material was discarded, while all live tissues were dried to constant weight $\left(60^{\circ} \mathrm{C}\right)$, weighed and archived.

Reproductive ecology. Reproductive effort (RE) was determined as the proportion of total shoot biomass allocated to sexual (flower parts) reproduction (Willson 1983, Reekie \& Bazzaz 1987). Fruit production was assessed using transects during summer 1996 (June to September). At each site, four $20 \mathrm{~m}$ transects were oriented east-to-west. At $2 \mathrm{~m}$ intervals along each transect, a $35 \times 35 \mathrm{~cm}$ quadrat was placed on the seagrass bed and the number of fruits were counted and recorded. The average number of seeds per fruit was assessed by counting the seeds released from individual fruits ( $\mathrm{n}=12$ during 1995, $\mathrm{n}=16$ during 1996).

Growth. Above-ground leaf growth was determined using a modification of the Zieman leaf marking technique (Zieman 1974). A $35 \times 35 \mathrm{~cm}$ quadrat was haphazardly placed in the grass bed and all shoots were marked for growth using a hypodermic needle. The needle was pushed through the middle of the bundle sheath of each, permanently marking all leaf material. After about $1 \mathrm{mo}$, marked shoots were collected and the amount of new leaf material (all tissues between the scar on bundle sheath and scars on the standing leaves) was measured on 10 to 15 shoots. Leaf growth and production were calculated using the equations presented by Dennison (1990a).

A new rhizome marking technique was developed because the architecture of Thalassia testudinum does not lend itself to traditional rhizome tagging methods (Dennison 1990b). By fanning away the sediments, rhizome meristems were located along the edge of bare patches. An insect pin (stainless steel, 00 gauge) was inserted about $1.5 \mathrm{~cm}$ behind the meristem to avoid damaging the sensitive tissues. A plastic surveyors flag was then inserted in the sediment directly adjacent to the needle marking the exact location of the rhizome. The rhizome was then re-buried with the dislodged sediments. After about $1 \mathrm{mo}$, the marked rhizome segments were retrieved and returned on ice to the lab for processing. The original needle mark was located; tissue $>1.5 \mathrm{~cm}$ forward of that mark represented new growth formed after the rhizome was marked. Length, weight and number of new nodes (equivalent to new scale leaves) initiated were measured and recorded. Estimates of new growth were calculated per individual rhizome meristem on a daily basis. Annual esti- 
mates were made using numerical summation described below. Values were converted to a per $\mathrm{m}^{2}$ basis using rhizome meristem densities obtained from biomass cores. Average rhizome meristem density was $248 \mathrm{~m}^{-2}$ at the Shallow site and $100 \mathrm{~m}^{-2}$ at the Deep site.

To validate estimates of rhizome growth determined from the marking method, we used a boundary marking method. In a naturally formed bare area, a row of plastic poles ( $n=4$ to 6 poles) was deployed perpendicular to the growing edge of the seagrass bed. The plastic poles were driven into the sediments until the top of the pole was $1 \mathrm{~cm}$ above the water-sediment interface. A surveyor's flag was used to mark the location of the plastic poles. The distance between the center of each plastic pole and the nearest seagrass shoot was measured and recorded on an underwater slate. After a period of about $1 \mathrm{yr}$, the measurements were repeated and the annual elongation rate calculated.

Production calculations. Annual production estimates were calculated using numerical summation techniques. Daily leaf and rhizome production rates, calculated from marking plants, were multiplied by the number of days in the month. Monthly values were summed for the period January to December 1996 to derive annual estimates reflective of seasonal changes over the year. Gaps in the production data-set were filled by interpolating between existing data points assuming a linear response.

Calculation of carbon and nitrogen incorporation. Annual carbon and nitrogen incorporation in Thalassia testudinum was derived from leaf and rhizome growth and $\mathrm{C}: \mathrm{N}$ ratios. For the purposes of this study, 'incorporation' was strictly defined as the amount of carbon and nitrogen allocated to new tissues and should not be confused with metabolic requirements. Carbon and nitrogen content of leaf and rhizome tissues from Stn 2 during 1996 were analyzed using an elemental analyzer (Carlo-Erba EA 1108). Monthly production rates were multiplied by the $\% \mathrm{C}$ and $\mathrm{N}$ content to obtain estimates of $\mathrm{C}$ and $\mathrm{N}$ incorporation into newly formed tissues. Monthly estimates were summed as described above.

Statistical analyses. Statistical analyses were performed using SigmaStat (Jandel Scientific, San Rafael, CA). Differences in daily underwater PFD, water column nitrate + nitrite, ammonium, chl a, and sediment $\mathrm{NH}_{4}{ }^{+}$as well as Thalassia testudinum biomass, growth, and reproductive effort were analyzed using 2-way ANOVA with main effects of site and month. Calculation of the percent change between sites or months was based on ANOVA means. Reproductive effort data were arc-sine transformed prior to analysis. Assumptions of normality and homogeneity of variance were tested and when assumptions were not satisfied, analyses were performed on transformed data. How- ever, the results of analyses on transformed and untransformed data were identical in all cases, so only untransformed analyses are presented. Statistical significance was set at the alpha $<0.05$ level and Student-Newman-Keuls multiple comparisons test was used to further examine significant differences. Correlation analysis was used to examine relationships between plant growth and temperature, underwater PFD and daylength.

\section{RESULTS}

\section{Physical and chemical parameters}

Average monthly water temperature ranged from $30^{\circ} \mathrm{C}$ in summer to $15^{\circ} \mathrm{C}$ during winter (Fig. 2). Surface PFD during summer was 3 -fold higher than winter. Overall, average daily underwater PFD was site-specific (Table 1), with values from the Deep site $10 \%$ lower than from the Shallow site (Fig. 2). Annual underwater PFD calculated using numerical summation at the Deep site was 2923 and $7040 \mathrm{~mol}$ photons
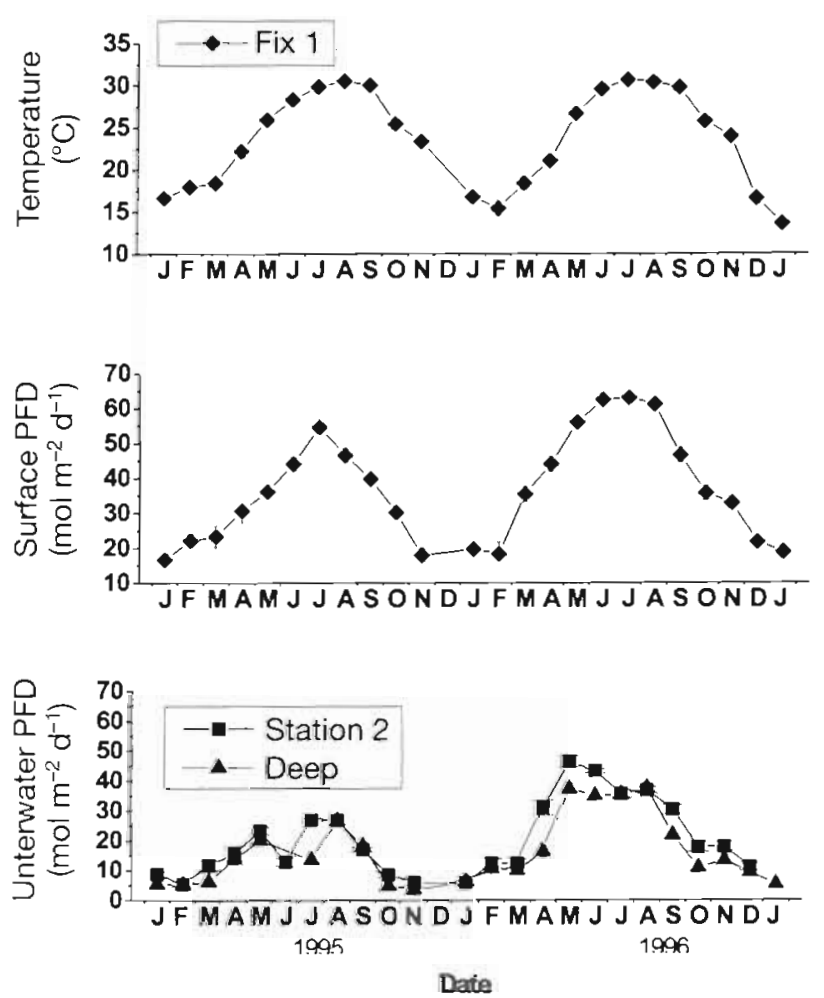

Fig. 2. Temperature and surface photon flux density (PFD) from Fix 1, underwater PFD from Stn 2 and the Deep sampling site in Lower Laguna Madre from January 1995 to January 1997. PFD data from $\operatorname{Stn} 2$ were used to approximate conditions at the Shallow site. Values represent mean \pm SE 
Table 1. Summary of ANOVA results for underwater irradiance, water column and sediment chemistry and seagrass biological measurements. Irradiance, chemical and biological measurements are the dependent variables, while site and month are the independent variables. Degrees of freedom (df), mean squares (MS), site by month interaction ( $\mathrm{S} \times \mathrm{M}$ ) and residuals (Resid)

\begin{tabular}{|c|c|c|c|c|c|}
\hline Dependent & Source & $\mathrm{df}$ & MS & $F$-ratio & $p$ value \\
\hline Underwater & Site & 1 & 937.5 & 10.9 & 0.0010 \\
\hline \multirow[t]{3}{*}{ irradiance } & Month & 11 & 11228.5 & 130.4 & $<0.0001$ \\
\hline & $\mathrm{S} \times \mathrm{M}$ & 11 & 477.7 & 5.6 & $<0.0001$ \\
\hline & Resid & 1234 & 86.1 & & \\
\hline Nitrate + & Site & 2 & 0.29 & 1.78 & 0.1710 \\
\hline \multirow{3}{*}{ nitrite } & Month & 10 & 1.58 & 9.69 & $<0.0001$ \\
\hline & $S \times M$ & 20 & 0.19 & 1.15 & 0.3010 \\
\hline & Resid & 223 & 0.16 & & \\
\hline \multirow[t]{4}{*}{ Ammonium } & Site & 2 & 0.43 & 2.11 & 0.1240 \\
\hline & Month & 10 & 6.09 & 29.89 & $<0.0001$ \\
\hline & $\mathrm{S} \times \mathrm{M}$ & 20 & 0.78 & 3.81 & $<0,0001$ \\
\hline & Resid & 221 & 0.20 & & \\
\hline \multirow[t]{4}{*}{ Chlorophyll a } & Site & 2 & 82.1 & 2.07 & 0.1282 \\
\hline & Month & 10 & 485.1 & 12.25 & $<0.0001$ \\
\hline & $\mathrm{S} \times \mathrm{M}$ & 20 & 56.9 & 1.44 & 0.1079 \\
\hline & Resid & 211 & 39.6 & & \\
\hline \multirow{4}{*}{ Sediment $\mathrm{NH}_{4}{ }^{+}$} & Site & 1 & 3217.7 & 14.4 & 0.0004 \\
\hline & Month & 3 & 1919.0 & 8.59 & $<0.0001$ \\
\hline & $\mathrm{S} \times \mathrm{M}$ & 3 & 1691.0 & 7.57 & 0.0002 \\
\hline & Resid & 56 & 233.4 & & \\
\hline \multirow[t]{4}{*}{ Total biomass } & Site & 1 & 9701381.7 & 231.8 & $<0.0001$ \\
\hline & Month & 9 & 144548.7 & 3.4 & 0.0008 \\
\hline & $\mathrm{S} \times \mathrm{M}$ & 9 & 121701.8 & 2.9 & 0.0037 \\
\hline & Resid & 123 & 41841.5 & & \\
\hline \multirow[t]{4}{*}{ Density } & Site & 1 & 9701381.7 & 69.2 & $<0.0001$ \\
\hline & Month & 9 & 144548.7 & 1.7 & 0.0882 \\
\hline & $\mathrm{S} \times \mathrm{M}$ & 9 & 121701.8 & 0.9 & 0.5345 \\
\hline & Resid & 123 & 41841.5 & & \\
\hline \multirow[t]{4}{*}{ Leaf production } & Site & 1 & 13.9 & 24.1 & $<0.0001$ \\
\hline & Month & 7 & 9.6 & 16.8 & $<0.0001$ \\
\hline & $\mathrm{S} \times \mathrm{M}$ & 7 & 3.8 & 6.6 & $<0.0001$ \\
\hline & Resid & 242 & 0.5 & & \\
\hline \multirow[t]{4}{*}{ Rhizome production } & Site & 1 & 6.9 & 66.39 & $<0.0001$ \\
\hline & Month & 4 & 0.22 & 2.11 & 0.0930 \\
\hline & $S \times M$ & 4 & 0.05 & 0.51 & 0.7267 \\
\hline & Resid & 49 & & & \\
\hline \multirow[t]{4}{*}{ Sexual reproduction effort } & Site & 2 & 0.007 & 0.885 & 0.4148 \\
\hline & Month & 9 & 0.141 & 17.2 & $<0.0001$ \\
\hline & $\mathrm{S} \times \mathrm{M}$ & 18 & 0.022 & 2.7 & 0.0005 \\
\hline & Resid & 158 & 0.008 & & \\
\hline
\end{tabular}

$\mathrm{m}^{-2} \mathrm{yr}^{-1}$, equivalent to 31 and $56 \%$ Surface Irradiance (\% SI) during 1995 and 1996, respectively. At the Shallow site annual PFD was 4292 and 9149 mol photons $\mathrm{m}^{-2} \mathrm{yr}^{-1}$, equivalent to 37 and $70 \%$ SI during 1995 and 1996, respectively. Underwater daylength varied between $10 \mathrm{~h}$ during January and $14 \mathrm{~h}$ during summer (April through May).

There was no statistical difference between the Shallow and Deep sites for water column $\mathrm{NH}_{4}{ }^{+}$and $\mathrm{NO}_{3}{ }^{-}+\mathrm{NO}_{2}{ }^{-}$(Table 1). Average monthly water column $\mathrm{NH}_{4}{ }^{+}$values were highest during May 1995. Variability resulted in a statistically significant site $x$ month interaction term (Table 1). Water column nitrate + nitrite was variable, ranging between 0 and $3 \mu \mathrm{M}$, with lowest monthly values recorded during late winter 1995 (Fig. 3, Table 1). Water column chl a values ranged

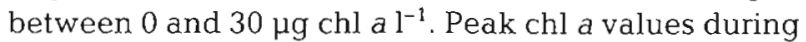
winter months were significantly higher than during any other month (Table 1). Elevated chl a during winter was caused by storms advecting the brown tide algal bloom from Upper Laguna into LLM. Summer chl a values were almost always near $0 \mu \mathrm{g}$ chl a $\mathrm{l}^{-1}$ (Fig. 3) and there was no significant difference in pigment concentration between sites (Table 1).

Sediment porewater ammonium values ranged between 15 and $80 \mu \mathrm{M}$; however, most values were be- 

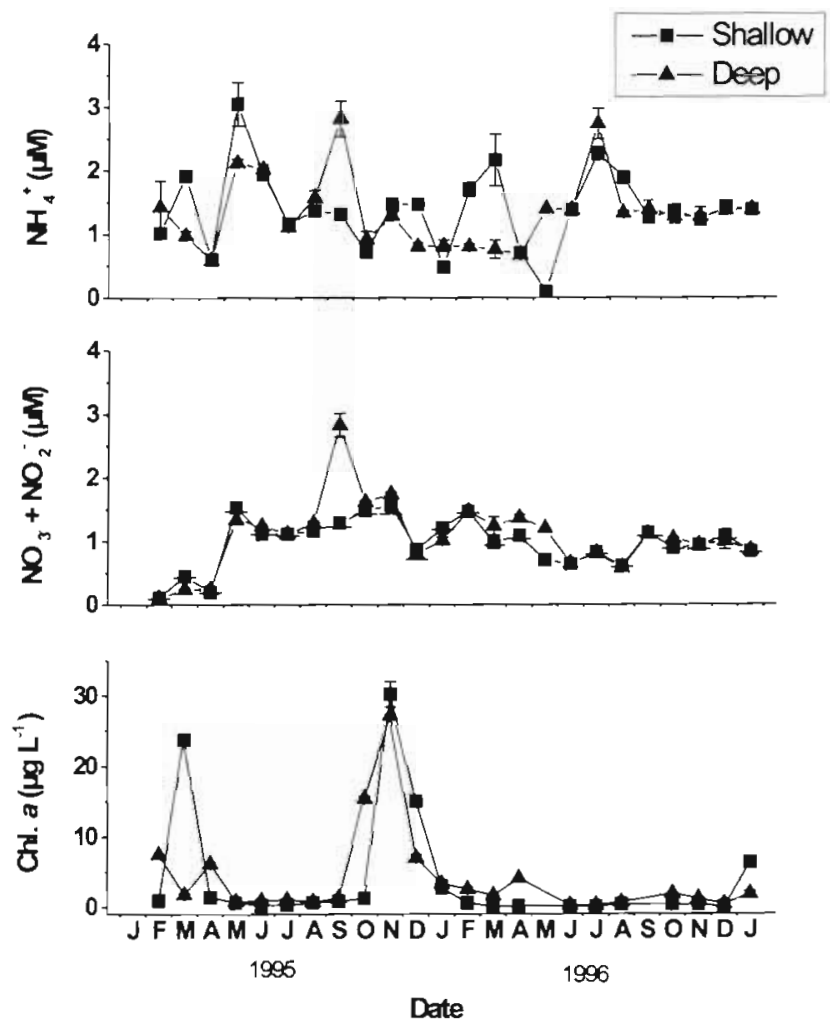

Fig. 3. Water column ammonium, nitrate + nitrite and chlorophyll a values from the Shallow and Deep sampling sites measured monthly between February 1995 and January 1997 Values represent mean $\pm \mathrm{SE}, \mathrm{n}=4$

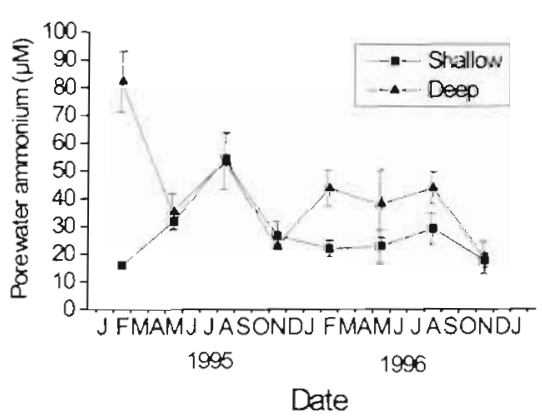

Fig. 4. Sediment porewater ammonium from the Shallow and Deep sampling sites measured quarterly between February 1995 and November 1996. Values represent mean \pm SE, $n=4$

tween 25 and $55 \mu \mathrm{M}$ (Fig. 4). Average sediment $\mathrm{NH}_{4}{ }^{+}$ values at the Deep site were $35 \%$ higher than at the Shallow site (Table 1). Porewater ammonium values varied between months, mean values during February and August were higher than May and November valves (Table 1). Sediments from both sites were characterized as 55 to $65 \%$ sand, 10 to $15 \%$ silt, 15 to $20 \%$ clay and $<10 \%$ rubble.
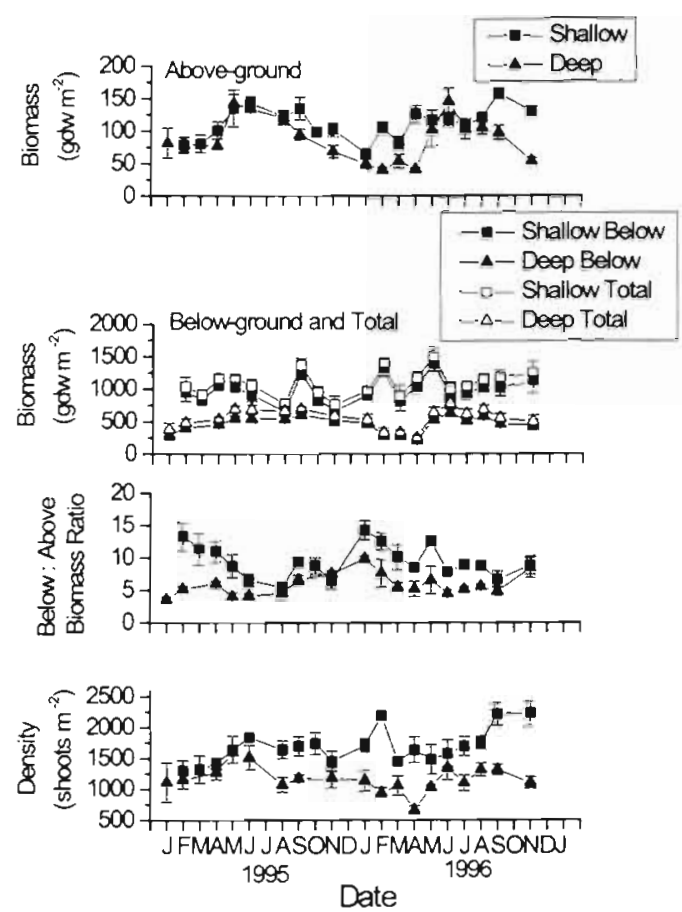

Fig. 5. Thalassia testudinum biomass and shoot density Above-ground, total and below-ground biomass, the ratio of below-:above-ground biomass and shoot density at the Shallow and Deep sites measured monthly between January 1995 and November 1996. Values represent mean $\pm \mathrm{SE}, \mathrm{n}=4$

\section{Seagrass biomass and growth}

Total biomass at the Shallow site ranged between 800 and $1400 \mathrm{~g} \mathrm{DW} \mathrm{m}^{-2}$, while biomass at the Deep site ranged from 250 to $700 \mathrm{~g} \mathrm{DW} \mathrm{m} \mathrm{m}^{-2}$ (Fig. 5). Total biomass at the Shallow site was 20 to $50 \%$ higher than at the Deep site and peak biomass occurred during spring and summer months (Fig. 5, Table 1). The below-ground biomass component accounted for 80 and $90 \%$ of the total biomass at the deep and Shallow sites respectively. At the Shallow site total and below-ground biomass did not exhibit a seasonal pattern, probably as a result of spatial heterogeneity (Fig. 5), while there appears to be a seasonal pattern at the Deep site. Above-ground biomass exhibited peak biomass during summer months and minimum biomass during winter months (Fig. 5). The ratio of below-to above-ground biomass ( $B$ : A ratio) ranged between 4 and 14, with minimal values during the summer (Fiq. 5). Thalassia testudinum shoot density ranged between 700 and 2200 shoots $\mathrm{m}^{-2}$ (Fig. 5). Shoot density at the Shallow site was about 5 to $60 \%$ higher than at the Deep site, but variability between months obscured any seasonal patterns (Table 1).

Above-ground production rates at the Shallow site were $25 \%$ higher than at the Deep site and peak leaf 

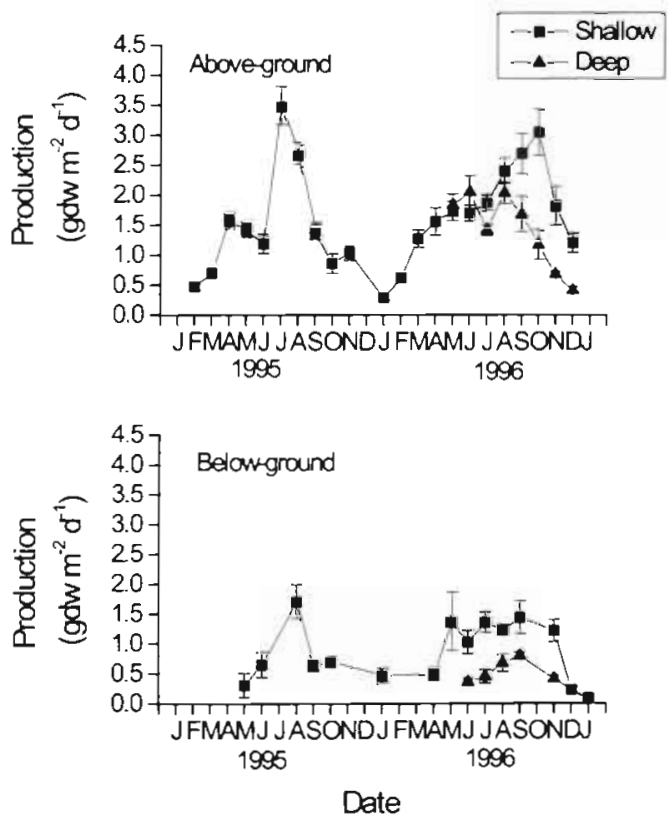

Fig. 6. Thalassia testudinum above- and below-ground areal production rates at the Shallow and Deep sites measured monthly between February 1995 and December 1996 (aboveground) and January 1997 (below-ground). Values represent mean $\pm \mathrm{SE}, \mathrm{n}=4$

production rates $\left(3.5 \mathrm{~g} \mathrm{DW} \mathrm{m}^{-2} \mathrm{~d}^{-1}\right)$ occurred during late summer with minimum production $\left(0.4 \mathrm{~g} \mathrm{DW} \mathrm{m}^{-2}\right.$ $\mathrm{d}^{-1}$ ) during the winter (Fig. 6). Differences between the Shallow and Deep sites and sampling dates were statistically significant (Table 1). Below-ground production values exhibited similar patterns with values ranging between 0.1 and $1.7 \mathrm{~g} \mathrm{DW} \mathrm{m}^{-2} \mathrm{~d}^{-1}$ (Fig. 6). Rhizome production rates at the Shallow site were $50 \%$ higher than at the Deep site and although highest growth rates occurred in September the differences among all months were not statistically significant (Table 1). The annual rhizome elongation rate was estimated as $55 \pm$ $6 \mathrm{~cm}$ plant $^{-1} \mathrm{yr}^{-1}$ using rhizome marking and about 50 to $60 \mathrm{~cm}$ plant $^{-1} \mathrm{yr}^{-1}$ using the boundary marking method.

\section{Calculated production and C:N ratios}

At the Shallow site leaf production during 1995 was $491 \pm 46 \mathrm{~g} \mathrm{DW} \mathrm{m}^{-2} \mathrm{yr}^{-1}$ and $614 \pm 71 \mathrm{~g} \mathrm{DW} \mathrm{m}^{-2} \mathrm{yr}^{-1}$ in 1996 , a $20 \%$ difference between years. The rhizome growth rate during 1996 was $338 \pm 65 \mathrm{~g} \mathrm{DW} \mathrm{m}^{-2} \mathrm{yr}^{-1}$, which was $50 \%$ lower than leaf growth rates. Additionally, there was a strong relationship between above- and below-ground growth $(\mathrm{r}=0.79, \mathrm{n}=13)$. Leaves had peak carbon content during September and highest nitrogen during March (Table 2). Leaf C:N ratios were 21 to 25 during summer and about 14.6 during spring. Rhizome C:N ratios varied between 45 and 62, with lowest values during winter and spring (Table 2).

A detailed growth, carbon and nitrogen budget was developed for Thalassia testudinum in LLM during 1996 (Table 3). Annual production calculated using a numerical summation method on monthly estimates of aboveand below-ground growth was $953 \mathrm{~g} \mathrm{DW} \mathrm{m}^{-2} \mathrm{yr}^{-1}$ (Table 3). Monthly rates of leaf growth were estimated to range between 8 and $93 \mathrm{~g} \mathrm{DW} \mathrm{m}^{-2} \mathrm{yr}^{-1}$, with rhizome growth ranging between 13 and $42 \mathrm{~g} \mathrm{DW} \mathrm{m}^{-2} \mathrm{yr}^{-1}$ (Table 3). Using the measured $\mathrm{C}: \mathrm{N}$, we calculated that $T$. testudinum in LLM incorporates $340 \mathrm{~g} \mathrm{C} \mathrm{m}^{-2} \mathrm{yr}^{-1}$ and $14.7 \mathrm{~g} \mathrm{~N} \mathrm{~m}^{-2} \mathrm{yr}^{-1}$ into all of its tissues. In leaf tissue, $\mathrm{C}$ incorporation ranged between 2.9 and $34.8 \mathrm{~g} \mathrm{C} \mathrm{m}^{-2} \mathrm{mo}^{-1}$, while in rhizomes values ranged between 4.7 and $16.1 \mathrm{~g}$ $\mathrm{C} \mathrm{m}^{-2} \mathrm{mo}^{-1}$. Nitrogen incorporation in leaf tissue varied between 0.2 and $1.6 \mathrm{~g} \mathrm{~N} \mathrm{~m}^{-2} \mathrm{mo}^{-1}$, while in rhizomes values fell between 0.6 and $0.3 \mathrm{~g} \mathrm{~N} \mathrm{~m}^{-2} \mathrm{mo}^{-1}$ (Table 3).

\section{Reproductive ecology}

Sexual reproductive effort (RE) ranged between 0 and $16 \%$ of above-ground biomass (Fig. 7). Statistical analysis of sexual RE indicated no significant differences between the shallow and Deep sites, but sexual RE was higher during April, May and June than during any other month (Fig. 7, Table 1). Sexual RE at the Shallow site was correlated with underwater PFD and

Table 2. Percent carbon, nitrogen and calculated C:N ratio for Thalassia testudinum leaf and rhizome tissues from Stn 2 in Lower Laguna Madre, Texas. Values are mean $\pm \mathrm{SE}, \mathrm{n}=\mathbf{4}$

\begin{tabular}{|lcccccc|}
\hline Date & $\begin{array}{c}\text { Leaf } \\
\% \mathrm{C}\end{array}$ & $\begin{array}{c}\text { Rhizome } \\
\% \mathrm{C}\end{array}$ & $\begin{array}{c}\text { Leaf } \\
\% \mathrm{~N}\end{array}$ & $\begin{array}{c}\text { Rhizome } \\
\% \mathrm{~N}\end{array}$ & $\begin{array}{c}\text { Leaf } \\
\text { C:N }\end{array}$ & $\begin{array}{c}\text { Rhizome } \\
\text { C:N }\end{array}$ \\
\hline Sep 1995 & $36.1(0.3)$ & $35.2(0.5)$ & $2.0(0.0)$ & $0.8(0.1)$ & $21.1(0.1)$ & $51.3(5.7)$ \\
Jan 1996 & $33.6(0.4)$ & $35.1(0.2)$ & $2.3(0.0)$ & $0.9(0.1)$ & $17.0(0.2)$ & $45.5(3.9)$ \\
Mar 1996 & $33.9(0.4)$ & $35.0(0.5)$ & $2.7(0.1)$ & $0.9(0.1)$ & $14.6(0.3)$ & $45.2(6.5)$ \\
Jun 1996 & $35.5(0.8)$ & $35.3(0.3)$ & $1.7(0.1)$ & $0.8(0.1)$ & $25.4(0.5)$ & $51.4(3.1)$ \\
Sep 1996 & $37.1(0.7)$ & $37.4(0.2)$ & $1.7(0.1)$ & $0.7(0.1)$ & $25.4(1.0)$ & $62.3(5.7)$ \\
\hline
\end{tabular}


daylength $(\mathrm{r}=0.751$ and 0.519 respectively, $\mathrm{n}=17$ ). At the Deep site, sexual RE was not correlated with either parameter. As expected, light and temperature were highly correlated $(r=84, n=24)$.

During both 1995 and 1996, 13 to $30 \%$ of the shoots flowered and $<10 \%$ of shoots formed fruits (Table 4 ). Maximum fruit density ranged between 20 and 70 fruits $\mathrm{m}^{-2}$. Fruit density at the Shallow site was $40 \%$ higher than Stn 2, which was $140 \%$ higher than the Deep site (Table 4). At the Shallow site maximum fruit abundance occurred during July, while maximum abundance at the other sites occurred during June. The average number of seeds per fruit was $1.3 \pm 0.1$ and $1.8 \pm$ 0.2 seeds fruit ${ }^{-1}$ for 1995 and 1996 respectively (Table 4).

\section{DISCUSSION}

\section{Growth, production and biomass}

Seagrass growth and production are regulated by light availability, temperature and nutrient supply. In this study, we examined in situ plant production relative to differences in underwater PFD for a shallow and a deep Thalassia testudinum population. Above- and below-ground production was 25 and $50 \%$ higher at the Shallow site than at the Deep site. Similarly, Dixon \& Leverone (1995) measured leaf production rates at Shallow sites that were $40 \%$ higher than at Deep sites. In our study, site-specific production rates were a result of $10 \%$ lower underwater PFD at the deep relative to the Shallow site. Variable leaf production between 1995 and 1996 was related to interannual variability in underwater PFD. Leaf production increased by $100 \mathrm{~g} \mathrm{DW} \mathrm{m}^{-2} \mathrm{yr}^{-1}$ between 1995 and 1996 , concurrent with a $30 \%$ increase in daily underwater PFD. Differences in the underwater light environment were related to increased depth between sites and interannual variability in turbidity associated with dredging activity and local current patterns. Resuspension of recently deposited dredged material on the western side of LLM may have resulted in increased turbidity at the study site (Brown \& Kraus 1997). Turbidity from dredged deposits and algal blooms has

Table 3. Monthly and annual estimates of Thalassia testudinum leaf and rhizome growth, carbon and nitrogen incorporation at the Shallow site during 1996 in Lower Laguna Madre, Texas. Bold values were interpolated between existing data points assuming a linear response. Values represent mean $\pm \mathrm{SE}$

\begin{tabular}{|c|c|c|c|}
\hline & $\mathrm{gDW} \mathrm{m}^{-2} \mathrm{mo}^{-1}$ & $\mathrm{~g} C \mathrm{~m}^{-2} \mathrm{mo}^{-1}$ & $\mathrm{~g} \mathrm{~N} \mathrm{~m}^{-2} \mathrm{mo}^{-1}$ \\
\hline \multicolumn{4}{|l|}{ Leaf tissue } \\
\hline $\operatorname{Jan}$ & $8.77(1.18)$ & $2.95(0.40)$ & $0.20(0.03)$ \\
\hline Feb & $17.71(2.34)$ & $5.95(0.79)$ & $0.41(0.04)$ \\
\hline Mar & $39.44(4.47)$ & $13.37(1.52)$ & $1.06(0.12)$ \\
\hline Apr & $46.61(6.81)$ & $15.80(2.31)$ & $1.26(0.18)$ \\
\hline May & $53.65(4.96)$ & $19.05(1.76)$ & $0.91(0.08)$ \\
\hline Jun & $50.90(4.05)$ & $18.07(1.44)$ & $0.87(0.07)$ \\
\hline Jul & $57.70(4.24)$ & $20.48(1.50)$ & $0.98(0.07)$ \\
\hline Aug & $74.27(6.52)$ & $27.55(2.42)$ & $1.26(0.11)$ \\
\hline Sep & $80.20(10.10)$ & $29.76(3.75)$ & $1.36(0.17)$ \\
\hline Oct & $93.95(12.11\}$ & $34.86(4.49)$ & $1.60(0.21)$ \\
\hline Nov & $54.18(9.53)$ & $18.20(3.20)$ & $1.25(0.22)$ \\
\hline Dec & $37.05(4.93)$ & $12.45(1.66)$ & $0.85(0.11)$ \\
\hline Annual leaf production ${ }^{a}$ & $614.44(71.25)$ & $218.49(25.23)$ & $12.01(1.43)$ \\
\hline \multicolumn{4}{|l|}{ Rhizome tissue } \\
\hline Jan & $14.33(3.91)$ & $5.03(1.37)$ & $0.13(0.04)$ \\
\hline $\mathrm{Feb}$ & $13.63(3.40)$ & $4.78(1.19)$ & $0.12(0.03)$ \\
\hline Mar & $14.82(3.35)$ & $5.19(1.17)$ & $0.13(0.03)$ \\
\hline Apr & $14.61(2.99)$ & $5.11(1.05)$ & $0.13(0.03)$ \\
\hline May & $42.21(15.26)$ & $14.90(5.39)$ & $0.34(0.12)$ \\
\hline Jun & $30.78(5.82)$ & $10.86(2.05)$ & $0.25(0.05)$ \\
\hline Jul & $42.21(5.44)$ & $14.90(1.92)$ & $0.34(0.04)$ \\
\hline Aug & $38.05(2.91)$ & $14.23(1.09)$ & $0.27(0.02)$ \\
\hline Sep & $43.14(8.22)$ & $16.13(3.07)$ & $0.30(0.06)$ \\
\hline Oct & $41.23\{7.89\}$ & $15.42(2.65)$ & $0.20(0.05)$ \\
\hline Nov & $36.60(5.50)$ & $12.85(1.93)$ & $0.33(0.05)$ \\
\hline Dec & $7.21(1.33)$ & $2.53(0.47)$ & $0.06(0.01)$ \\
\hline Annual rhizome production ${ }^{2}$ & $338.82(65.22)$ & $121.94(23.35)$ & $2.69(0.52)$ \\
\hline Total production ${ }^{\circ}$ & $953.26(136.47)$ & $340.43(48.58)$ & $14.7(4.12)$ \\
\hline Units are $\mathrm{g} \mathrm{m}^{-2} \mathrm{yr}^{-1}$ & & & \\
\hline
\end{tabular}


Table 4. Thalassia testudinum population flowering and fruiting characteristics for the Shallow site, Stn 2 and the Deep site during 1995 and 1996. Values represent mean $\pm \mathrm{SE}$, nd $=$ no data

\begin{tabular}{|c|c|c|c|}
\hline Parameter & Site & 1995 & 1996 \\
\hline $\begin{array}{l}\text { Percent shoots } \\
\text { flowering }\end{array}$ & $\begin{array}{l}\text { Shallow } \\
\text { Stn } 2 \\
\text { Deep }\end{array}$ & $\begin{array}{c}33.0 \pm 6.0 \\
\text { nd } \\
14.5 \pm 7.5\end{array}$ & $\begin{array}{l}13.7 \pm 6.0 \\
21.9 \pm 8.0 \\
30.4 \pm 5.7\end{array}$ \\
\hline $\begin{array}{l}\text { Percent shoots } \\
\text { fruiting }^{b}\end{array}$ & $\begin{array}{c}\text { Shallow } \\
\text { Stn } 2 \\
\text { Deep }\end{array}$ & $\begin{array}{l}\text { nd } \\
\text { nd } \\
\text { nd }\end{array}$ & $\begin{array}{l}7.2 \pm 0.8 \\
4.3 \pm 0.9 \\
3.3 \pm 0.8\end{array}$ \\
\hline $\begin{array}{l}\text { Fruit density } \\
\text { (fruits } \mathrm{m}^{-2} \text { ) }\end{array}$ & $\begin{array}{c}\text { Shallow } \\
\text { Stn } 2 \\
\text { Deep }\end{array}$ & $\begin{array}{l}\text { nd } \\
\text { nd } \\
\text { nd }\end{array}$ & $\begin{array}{l}68.4 \pm 7.2 \\
47.8 \pm 5.3 \\
19.5 \pm 4.7\end{array}$ \\
\hline Average seeds fruit ${ }^{-1}$ & & $1.3 \pm 0.1$ & $1.8 \pm 0.2$ \\
\hline \multicolumn{4}{|c|}{$\begin{array}{l}\text { aBased on core estimates during } 1995 \text { and } 1996 \\
{ }^{b} \text { Based on transect estimates during } 1996\end{array}$} \\
\hline
\end{tabular}

been implicated in the loss of seagrass habitat from Laguna Madre (Onuf 1994). Although sediment ammonium values were different between the Shallow and Deep sites, there was no difference between years (Fig. 4). Thus, it is improbable that differences in porewater ammonium can account for the observed differences in production. Further, there were no differences in the other environmental parameters examined.

Annual leaf production estimated using numerical summation was $614 \pm 71 \mathrm{~g} \mathrm{DW} \mathrm{m}^{-2} \mathrm{yr}^{-1}$ (Table 3),

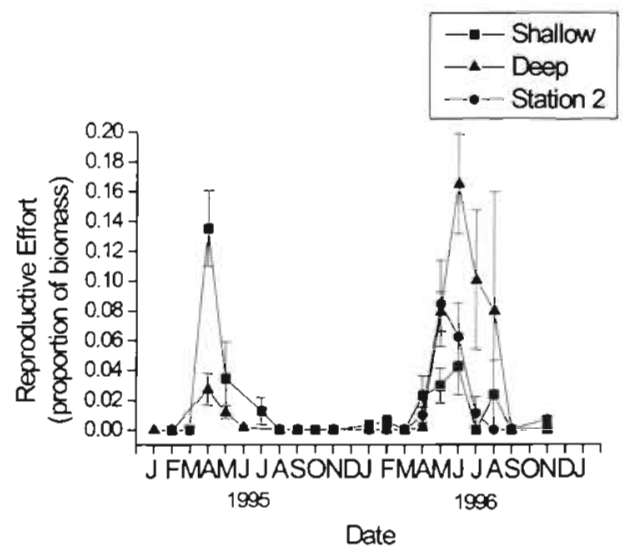

Fig. 7. Proportion of Thalassia testudinum biomass (mean \pm $\mathrm{SE}$ ) allocated to sexual reproduction at the Shallow and Deep sites between February 1995 and November 1996. At Stn 2 sampling was conducted between January and November 1996. Values represent mean $\pm \mathrm{SE}, \mathrm{n}=4$

which is low compared to tropical areas but similar to values for other sub-tropical regions (Table 5). Annual leaf production values from the Shallow site are similar to those reported for Thalassia testudinum populations along the mid-Texas coast (Corpus Christi Bay, Lee \& Dunton 1996), but were 30 to $60 \%$ higher than estimates from Tampa Bay, Florida (Dixon \& Leverone 1995). In the Mexican Caribbean, annual leaf production was 5 to $45 \%$ lower than this study, probably as a result of extreme oligotrophic conditions or depth dif-

Table 5. Thalassia testudinum. Above- and below-ground biomass and production of Thalassia sp. from various geographic areas. For comparison, all values were converted to represent annual production

\begin{tabular}{|c|c|c|c|c|c|c|}
\hline \multirow{2}{*}{$\begin{array}{l}\text { Species/ } \\
\text { location }\end{array}$} & \multirow[t]{2}{*}{ Depth $(\mathrm{m})$} & \multicolumn{2}{|c|}{ Biomass $\left(\mathrm{g} \mathrm{DW} \mathrm{m} \mathrm{m}^{-2}\right)$} & \multicolumn{2}{|c|}{ Production (g DW $\mathrm{m}^{-2} \mathrm{~d}^{-1}$ ) } & \multirow[t]{2}{*}{ Source } \\
\hline & & Above & Below & Above & Below & \\
\hline \multicolumn{7}{|c|}{ Thalassia testudinum } \\
\hline Barbados & - & - & - & 1131 & 1606 & Patriquin (1973) \\
\hline Bermuda & - & - & - & 5146 & 1606 & Patriquin (1973) \\
\hline Florida & 0.5 & $27-40$ & - & $111-280$ & - & Tomasko \& Lapointe (1991) \\
\hline Florida & 2.0 & $50-69$ & - & $395-500$ & - & Tomasko \& Lapointe (1991) \\
\hline Belize & 0.5 & $27-49$ & - & $242-484$ & - & Tomasko \& Lapointe (1991) \\
\hline Belize & 2.0 & $22-32$ & - & $181-328$ & - & Tomasko \& Lapointe (1991) \\
\hline Mexico & - & 379 & 345 & 2328 & $150-450$ & Gallegos et al. (1993) \\
\hline Mexico & $2.5-4.5$ & $15-80$ & - & $300-510^{\mathrm{b}}$ & - & van Tussenbroek (1995) \\
\hline Texas & 1.2 & $100-350$ & $200-300$ & $760^{\circ}$ & - & Lee \& Dunton (1996) \\
\hline Texas & 1.3 & $78-160$ & $647-1400$ & $543-685^{b}$ & $273-400^{b}$ & This study \\
\hline Texas & 1.7 & $40-140$ & $200-630$ & - & - & This study \\
\hline Florida & 1.6 & $20-200$ & - & $382^{b}$ & - & Dixon \& Leverone (1995) \\
\hline Florida & 2.0 & $4-30$ & - & $94^{\mathrm{b}}$ & - & Dixon \& Leverone (1995) \\
\hline \multicolumn{7}{|c|}{ Thalassia hemprichii } \\
\hline Philippines & - & 250 & 77 & 1511 & 22.8 & Vermaat et al. (1995) \\
\hline New Guinea & - & $22-56^{a}$ & $71-352^{a}$ & $693-1569^{a}$ & $51-215^{a}$ & Brouns (1985) \\
\hline Indonesia & $0.1-1.2$ & - & - & 1277.5 & - & Erftemeijer et al. (1993) \\
\hline
\end{tabular}


Table 6. Contribution of below-ground tissues to total biomass and production on a percentage basis

\begin{tabular}{|c|c|c|c|}
\hline Species & $\begin{array}{c}\text { Biomass } \\
(\%)\end{array}$ & $\begin{array}{c}\text { Production } \\
\qquad \%\}\end{array}$ & Source \\
\hline \multirow{3}{*}{$\begin{array}{l}\text { Thalassia } \\
\text { testudinum }\end{array}$} & - & $10-13$ & Patriquin (1973) \\
\hline & 48 & 10 & Gallegos et al. (1993) \\
\hline & $80-90$ & $25-35$ & This study \\
\hline \multirow{2}{*}{$\begin{array}{l}\text { Thalassia } \\
\text { hemprichii }\end{array}$} & - & $5-15$ & Erftemeijer et al (1993) \\
\hline & 24 & 1.5 & Vermaat et al. (1995) \\
\hline
\end{tabular}

ferences (Table 5; van Tussenbroek 1995). Seagrass growth and production from LLM were within the range of literature values reported and were site-specific over relatively small spatial scales (e.g. several $\mathrm{km}$ ). Additionally, growth patterns were correlated with local environmental conditions.

Annual rhizome production based on long-term in situ measurements was calculated as $121 \pm 23 \mathrm{~g} \mathrm{C} \mathrm{m}^{-2}$ $\mathrm{yr}^{-1}$, with monthly values ranging between 2.5 and 16.1 $\mathrm{g} \mathrm{C} \mathrm{m}^{-2} \mathrm{mo}^{-1}$ (Table 3). In the LLM Thalassia testudinum rhizome growth accounted for 25 to $35 \%$ of total production and 80 to $90 \%$ of the total biomass Additionally, rhizome production was tightly coupled to leaf production ( $\mathrm{r}=0.79, \mathrm{n}=13)$. In comparison, several researchers estimate that below-ground tissues account for 10 to $15 \%$ of whole plant production, with some estimates as low as 1.5\% (Table 6). Belowground production estimates from this study are substantially higher than previous reports for $T$. testudinum and are near the upper end of the range reported for seagrasses in general (Hillman et al. 1989). Consequently, studies that focus exclusively on leaf production underestimate total plant production by ignoring the contribution of the below-ground component.

Both rhizome and boundary marking methods provided comparable estimates of annual rhizome elongation (ca $60 \mathrm{~cm} \mathrm{yr}^{-1}$ ). In contrast, Duarte (1991a) using allometric methods estimated horizontal rhizome elongation in Thalassia testudinum at $150 \mathrm{~cm} \mathrm{yr}^{-1}$, while experimental work in Mexico (Gallegos et al. 1993) predicted rhizome elongation at 20 to $35 \mathrm{~cm} \mathrm{yr}^{-1}$ Future studies of seagrass production ecology require innovative methods for assessing root and vertical rhizome production. Caution must be used when interpreting rhizome growth rates, because rates at the edge of bare patches may not reflect rhizome growth within the meadow

Total annual production, calculated for the Shallow site $\left(340 \mathrm{~g} \mathrm{C} \mathrm{m}^{-2} \mathrm{yr}^{-1}\right)$ was low relative to earlier pub. lished estimates (McRoy \& McMillan 1977, Zieman \& Wetzel 1980). However, annual production can be overestimated when short-term studies of seagrass productivity conducted during periods of high produc- tion and favorable weather (i.e. summer) are extrapolated to a year. Data from this study indicate that summer leaf production rates can be $90 \%$ higher than winter production (Table 3). Thus, seasonal changes must be incorporated into annual estimates of seagrass production. Summation methods provide accurate production estimates (Herzka \& Dunton 1998) As a consequence of interannual variability, long-term studies encompassing more than 1 annual cycle are required to adequately estimate annual production. Areal production calculated from average shoot praduction ( $g$ DW shoot ${ }^{-1} \mathrm{~d}^{-1}$ ) and shoot density (shoots $\mathrm{m}^{-2}$ ) is sensitive to inaccuracies in density estimates. Preliminary work indicates that because of spatial heterogeneity at least ten $15 \mathrm{~cm}$ diameter core samples are required to obtain reasonable estimates of Thalassia testudinum shoot density (Kaldy unpubl. data).

Biomass values ranging between 200 and $1400 \mathrm{~g} \mathrm{DW}$ $\mathrm{m}^{-2}$ are consistent with previous reports for Thalassia testudinum from around the world (Table 5). The reduced biomass at the Deep site is also consistent with other studies that examined differences in depth (Table 5). Seagrass biomass often decreases near the deep edge of beds; however, site-specific character reversal has also been documented (Dawes \& Tomasko 1988, Duarte 1991b, Tomasko \& Lapointe 1991). At the Shallow site variability between samples obscured any seasonal biomass pattern that may have been present. Seasonal patterns of total biomass at the Deep site were a direct result of seasonal patterns in both the above-and below-ground tissues. In contrast, seasonal patterns in total $T$. testudinum biomass from the midTexas coast (Corpus Christi Bay [CCB]) were the result of seasonal changes in leaf biomass (Lee \& Dunton 1996). Local environmental conditions, particularly temperature, underwater PFD and nutrient availability, probably regulate observed differences in biomass patterns between northern (CCB) and southern (LLM) $T$ testudinum populations.

\section{Reproductive ecology}

The phenology of flowering and fruiting Thalassia testudinum beds in Texas was similar to the patterns described for Florida populations (Durako \& Moffier 1987). Flowering was distinctly seasonal, with 13 to $30 \%$ of the shoots flowering during April and May. Detailed examination of leaf and floral peduncle scars found that 28 to $38 \%$ of $T$. testudinum short shoots flower at least once during their life-span (Kaldy et al. 1999). Comparable flowering intensity has been reported from Fiorida and the Caribbean (Grey \& Moffler 1978, Moffler et al. 1981, Durako \& Moffler 1985, 1987, Gallegos et al. 1992). Flower fertilization probably 
occurred during late May and early June, since fruit development was noted in mid-June. Fruits matured and ripened during June and July and all fruit had dehisced by the end of August (Kaldy 1997). Floral primordia were present in a few samples taken during winter, indicating that floral development can occur during other times of the year (Durako \& Moffler 1987), which contradicts the findings of van Tussenbroek (1994) working in Mexico. But only a few shoots in LLM exhibited flower primordia during winter, suggesting that these shoots were precocious.

Sexual RE provides a method of quantifying allocation of biomass to sexual reproduction and may be a useful measure in future work, because it provides a first approximation of energy investment (Willson 1983, Reekie \& Bazzaz 1987). Thalassia testudinum flowers and fruits accounted for up to $16 \%$ of the total above-ground biomass, similar to estimates of terrestrial grass (Reekie \& Bazzaz 1987). Clonal growth is probably less of an energy investment than sexual reproduction, because young clonal shoots probably become photosynthetically self-sufficient quickly, whereas parental shoots provide stored reserves which seedlings may use for up to 2 mo before becoming photosynthetically self-sufficient (Kaldy \& Dunton 1999).

Flowering is energetically expensive (Hickman \& Pitelka 1975, Reekie \& Bazzaz 1987, Antos \& Allen 1994) and a wide variety of plants exhibit reduced growth rates during fruit and seed production (Brock 1983, Willson 1983, Lee 1988). Leaf production data plotted to represent leaf formation rates exhibit a 60 to $80 \%$ increase subsequent to fruit dehiscence (Kaldy et al. 1999). Additionally, carbon and nitrogen allocation patterns change during sexual reproduction (Haig \& Westoby 1988, Spencer et al. 1994, Saulnier \& Reekie 1995). Physiological studies have found that photosynthesis in reproductive structures can supply up to $50 \%$ of the carbon required for fruit production (Bazzaz \& Carlson 1979, Bazzaz et al. 1979, Williams et al. 1985). As a result, estimates of seagrass reproductive effort based on biomass allocation probably represent minimum estimates of energy investment. Critical evaluation of reproductive energy balance will require measures of biomass allocation, whole plant respiration and reproductive photosynthesis (Reekie \& Bazzaz 1987).

Daylength and temperature are important factors regulating endogenous rhythms including reproduction (Gwinner 1986, Lüning 1993, Lüning \& Kadel 1993). Several studies have concluded that temperature is the primary control of seagrass flowering (McMillan. 1976, 1980, 1982, Phillips et al. 1981). Lee \& Dunton (1996) reported that the interaction between water temperature and underwater PFD was important in regulating seasonal leaf elongation in Thalassia testudinum. In this study, leaf growth was correlated with tempera- ture, underwater PFD and daylength $(r=0.71,0.58$ and 0.54 respectively, $n=22$ ) at the Shallow site and with temperature and daylength $(r=0.83$ and 0.86 respectively, $n=10$ ) at the Deep site. Rhizome growth at the Shallow site was correlated with temperature and underwater PFD ( $r=0.58$ and 0.54, $\mathrm{n}=13$ ), but not daylength. Sexual RE exhibited a positive correlation with underwater PFD and with daylength $(r=0.75$ and $0.52, n=17$ ). Peak sexual RE occurred during April and May, subsequent to average daylength increasing from 12 to $14 \mathrm{~h} \mathrm{~d}^{-1}$. Thus, changes in temperature, daylength and light levels appear to influence grow th and flowering in $T$. testudinum; however, determining which factor controls seagrass growth and reproduction will be a complicated task. The auto-correlation between light and temperature $(r=0.84, n=24)$ prevents accurate assessment of the relationship between reproduction and the environment. Rigorous experimental work, involving controlled culture conditions will be required to determine which factors regulate seasonal patterns of seagrass growth and reproduction.

\section{Carbon and nitrogen incorporation}

Using measured tissue growth rates and $\mathrm{C}: \mathrm{N}$ ratios, we estimated the amount of carbon and nitrogen incorporated into new tissues. As a preliminary estimate, Thalassia testudinum incorporated $340 \mathrm{~g} \mathrm{C} \mathrm{m}^{-2} \mathrm{yr}^{-1}$ and $15 \mathrm{~g} \mathrm{~N} \mathrm{~m}^{-2} \mathrm{yr}^{-1}$ into plant tissues (Table 3), which is equivalent to $1.1 \times 10^{7} \mathrm{~kg} \mathrm{C} \mathrm{yr}^{-1}$ and $4.8 \times 10^{5} \mathrm{~kg} \mathrm{~N} \mathrm{yr}^{-1}$ for all the Thalassia in LLM. However, these estimates do not reflect the plants, metabolic requirements, which are probably much higher. Lee \& Dunton (1999) estimated annual $\mathrm{N}$ acquisition to be $53 \mathrm{~g} \mathrm{~N} \mathrm{~m}^{-2} \mathrm{yr}^{-1}$ in LLM using whole-plant $N$ uptake experiments and suggested that $>50 \%$ of $\mathrm{N}$ uptake was not incorporated into biomass. Monthly values of carbon incorporation are comparable to rates calculated from photosynthetic work (Herzka \& Dunton 1998); however, little work has been done on nitrogen assimilation in $T$. testudinum. We estimate that in LLM, the production of new tissues requires about 10 to $60 \mathrm{mg} \mathrm{N} \mathrm{m} \mathrm{N}^{-2} \mathrm{~d}^{-1}$, with minimum requirements during winter. In comparison, Moriarity \& Boon (1989) suggest that daily nitrogen requirements of most seagrasses range between 10 and $450 \mathrm{mg} \mathrm{N} \mathrm{m}^{-2}$ $\mathrm{d}^{-1}$ (11 and $70 \mathrm{mg} \mathrm{N} \mathrm{m}^{-2} \mathrm{~d}^{-1}$ for Thalassia sp.).

\section{SUMMARY AND CONCLUSIONS}

Long-term monitoring of seagrass biomass, production and reproductive ecology concurrent with environmental parameters indicates that seasonal fluctuations are the dominant controls on seagrass growth 
and production. Local environmental conditions, particularly temperature, underwater PFD and nutrient availability, probably regulate observed differences in biomass patterns between Thalassia testudinum populations. Assessment of total plant productivity must incorporate seasonal patterns, reproductive costs and the large fraction of production occurring in the belowground tissues. Failure to adequately estimate rhizome growth dramatically underestimates seagrass production. The phenology of flowering and fruiting of $T$. testudinum beds in Texas was distinctly seasonal, with 13 to $30 \%$ of the shoots flowering during April and May. The annual flowering event represents a substantial resource (e.g. carbon and nitrogen) investment, which may influence individual plant production.

Acknowledgements. This work was completed in partial fulfillment of the PhD requirements from the University of Texas at Austin, Marine Science Department by J.E.K. C. Chiscano, S. Herzka and K. S. Lee provided valuable comments and assisted in the field. K. Jackson, K. Major, H. Miller, S. Schonberg and C. Weilhoffer provided comments and provided assistance. $\mathrm{N}$ Fowler, E. Ingall, P. Montagna and C. Onuf provided valuable comments and discussion. D. Hockaday at UT-Pan American Coastal studies lab provided laboratory space. C. Brown, formerly at Conrad Blucher Institute, kindly provided terrestrial irradiance and temperature data. Four anonymous reviewers provided valuable comments which improved the manuscript. This work was supported by grants to K.H.D. from the Texas Higher Education Coordinating Board Advanced Research Program (Grant no. 003658-419) and the EPA Gulf of Mexico Program (Grant no. MX994713-95-2). Salary support was provided in part by the UTMSI Lund Fellowship awarded to J.E.K. This is contribution no. 1090 from UTMSI.

\section{LITERATURE CITED}

Antos JA, Allen GA (1994) Biomass allocation among reproductive structures in the dioecious shrub Oemleria cerasiformis-a functional interpretation. J Ecol 82:21-29

Bazzaz FA, Carlson RW (1979) Photosynthetic contribution of flowers and seeds to reproductive effort of an annual colonizer. New Phytol 82:223-232

Bazzaz. FA, Carlson RW, Harper JL (1979) Contribution to reproductive effort by photosynthesis of flowers and fruits. Nature 279:554-555

Brock MA (1983) Reproductive allocation in annual and perennial species of the submerged aquatic halophyte Ruppia. J Ecol 71:811-818

Brouns JWM (1985) A comparison of the annual production and biomass in three monospecific stands of the seagrass Thalassia hemprichii (Ehrenb.) Aschers. Aquat Bot 23:149-175

Brown CA, Kraus NC (1997) Environmental monitoring of dredging and processes in Lower Laguna Madre, Texas Final Roport to IS Arrny Corps of Engineers District, Galveston, Galveston, TX, TAMU-CC-CBI-96-01

Burd AB, Eldridge PM (1997) Modeling the effects of incident light and sediment geochemistry on seagrass production. Abstract 14th Estuarine Research Federation Conference. Providence, RI Estuarine Research Federation, Port Republic, MD

Czerny AB, Dunton KH (1995) The effects of in situ irradiance reduction on the growth of two subtropical seagrasses, Thalassia testudinum and Halodule wrightii. Estuaries 18: $418-427$

Dawes CJ, Tomasko DA (1988) Depth distribution of Thalassia testudinum in two meadows on the west coast of Florida; a difference in effect of light availability. PSZN I: Mar Ecol 9:123-130

Dennison WC (1990a) Leaf production. In: Phillips RC, McRoy CP (eds) Seagrass research methods. UNESCO, Paris, p $77-80$

Dennison WC (1990b) Rhizome/root production. In: Phillips RC, McRoy CP (eds) Seagrass research methods. UNESCO, Paris, p 81-82

Dixon LK, Leverone JR (1995) Irradiance requirements of Thalassia testudinum in Tampa Bay, Florida. Final Report to Surface Water Improvement and Management Program, Southwest Florida Water Management District, Tampa, FL. Mote Marine Laboratory Tech Rep 45

Duarte CM (1991a) Allometric scaling of seagrass form and productivity. Mar Ecol Prog Ser 77:289-300

Duarte CM (1991b) Seagrass depth limits. Aquat Bot 40: 363-377

Dunton KH (1994) Seasonal growth and biomass of the subtropical seagrass Halodule wrightii in relation to continuous measurements of underwater irradiance. Mar Biol $120: 479-489$

Dunton KH (1996) Photosynthetic production and biomass of the subtropical seagrass Halodule wrightii along an estuarine gradient. Estuaries 19:436-447

Durako MJ, Moffler MD (1985) Observations on the reproductive ecology of Thalassia testudinum (Hydrocharitaceae). III. Spatial and temporal variations within a seagrass bed. Aquat Bot 22:265-276

Durako MJ, Moffler MD (1987) Factors affecting the reproductive ecology of Thalassia testudinum (Hydrocharitaceaej. Aquat Bot 27:79-95

Erftemeijer PLA, Osinga R, Mars AE (1993) Primary production of seagrass beds in South Sulawesi (Indonesia): a comparison of habitats, methods and species. Aquat Bot 46:67-90

Folk RL (1964) Petrology of sedimentary rocks. Hemphill's Press, Austin, TX

Gallegos ME, Merino M, Marba N, Duarte CM (1992) Flowering of Thalassia testudinum Banks ex Konig in the Mexican Caribbean: age-dependence and interannual variability. Aquat Bot 43:249-255

Gallegos ME, Merino M. Marba N, Duarte CM (1993) Biomass and dynamics of Thalassia testudinum in the Mexican Caribbean: elucidating rhizome growth. Mar Ecol Prog Ser 95:185-192

Grey WF, Moffler MD (1978) Flowering of the seagrass Thalassia testudinum (Hydrocharitaceae) in the Tampa Bay, Florida area. Aquat Bot 5:251-259

Gwinner E (1986) Circannual rhythms. Springer-Verlag, Berlin

Haig D. Westoby M (1988) Inclusive fitness, seed resources and maternal care. In: Lovett-Doust J, Lovett-Doust L (eds) Plant reproductive ecology. Oxford University Press, Oxford, p $60-79$

Herzka SZ, Dunton KH (1997) Seasonal photosynthetic patterns of the seagrass Thalassia testudinum in the western Fulf of Mexion Mar Ficol Prog Ser 152:103-117

Herzka SZ, Dunton KH (1998) Light and carbon balance in the seagrass Thalassia testudinum: evaluation of current production models. Mar Biol 132:711-721.

Hickman IC, Pitelka LF (1975) Dry weight indicates energy allocation in ecological strategy analysis of plants. Oecologia 21:117-121

Hillman K, Walker DI, Larkum AWD, MCComb AJ (1989) Pro- 
ductivity and nutrient limitation. In: Larkum AWD. McComb AJ, Shepard SA (eds) Biology of seagrasses. Elsevier, Amsterdam p 635-685

Kaldy JE (1997) Production dynamics, reproductive ecology and demography of Thalassia testudinum (turtle grass) from the Lower Laguna Madre, Texas. Doctoral dissertation, University of Texas at Austin, Austin, TX

Kaldy JE, Dunton KH (1999) Ontogenetic photosynthetic changes, dispersal and survival of Thalassia testudinum (turtle grass) seedlings in a sub-tropical lagoon. J Exp Mar Biol Ecol 240:193-212

Kaldy JE, Fowler N, Dunton KH (1999) Critical assessment of Thalassia testudinum (turtle grass) aging techniques: implications for demographic inference. Mar Ecol Prog Ser $181: 279-288$

Lee KS, Dunton KH (1996) Production and carbon reserve dynamics of the seagrass Thalassia testudinum in Corpus Christi Bay, Texas, USA. Mar Ecol Prog Ser 143:201-21.0

Lee KS, Dunton KH (1997) Effects of in situ light reduction on the maintenance, growth and partitioning of carbon resources in Thalassia testudinum Banks ex König. J Exp Mar Biol Ecol 210:53-73

Lee KS, Dunton KH (1999) Inorganic nitrogen acquisition in the seagrass Thalassia testudinum: development of a wholeplant nitrogen budget. Limnol Oceanogr 44:1204-1215

Lee TD (1988) Patterns of fruit and seed production. In: Lovett-Doust J, Lovett-Doust L (eds) Plant reproductive ecology. Oxford University Press, Oxford, p 179-202

Lewis RR, Phillips RC (1980) Occurrence of seeds and seedlings of Thalassia testudinum Banks ex König in the Florida Keys (USA). Aquat Bot 9:377-380

Lüning $\mathrm{K}$ (1993) Environmental and internal control of seasonal growth in seaweeds. Hydrobiologia 260/261:1-14

Lüning $K$, Kadel P (1993) Daylength range for circannual rhythmicity in Pterygophora californica (Alariaceae, Phaeophyta) and synchronization of seasonal growth by daylength cycles in several other brown algae. Phycologia 32: $379-387$

McMillan C (1976) Experimental studies on flowering and reproduction in seagrasses. Aquat Bot 2:87-92

McMillan C (1980) Flowering under controlled conditions by Cymodocea serrulata, Halophila stipulacea, Syringodium isoetifolium, Zostera capensis and Thalassia hemprichis from Kenya. Aquat Bot 8:323-336

McMillan C (1982) Reproductive physiology of tropical seagrasses. Aquat Bot 14:245-258

McRoy CP, McMillan C (1977) Production ecology and physiology of seagrasses. In: McRoy CP, Helfferich C (eds) Seagrass ecosystems: a scientific perspective. Marcel Dekker, Inc, New York, p 53-87

Moffler MD, Durako MJ, Grey WF (1981) Observations on the reproductive ecology of Thalassia testudinum (Hydrocharitacede). Aquat Bot 10:183-187

Moriarty DJW, Boon PI (1989) Interactions of seagrasses with sediment and water. In: Larkum AWD, McComb AJ, Shepard SA (eds) Biology of seagrasses. Elsevier, Amsterdam, p 500-535

Onuf CP (1994) Seagrasses, dredging and light in Laguna Madre, Texas, USA. Estuar Coast Shelf Sci 39:75-91

Onuf CP (1996) Biomass patterns in seagrass meadows of the Laguna Madre, Texas. Bull Mar Sci 58:404-420

Orpurt PA, Boral LL (1964) The flowers, fruits and seeds of Thalassia testudinum Koenig. Bull Mar Sci Gulf Caribb 14: 296-302

Parsons TR, Maita Y, Lalli CM (1984) A manual of chemical and biological methods for seawater analysis. Pergamon Press, New York
Patriquin D (1973) Estimation of growth rate, production and age of the marine angiosperm Thalassia testudinum König. Caribb J Sci 1.3:111-123

Phillips RC. McMillan C, Bridges KW (1981) Phenology and reproductive physiology of Thalassia testudinum from the western tropical Atlantic. Aquat Bot 11:263-277

Pirc H (1989) Seasonal changes in soluble carbohydrates, starch and energy content in Mediterranean seagrasses. PSZN I: Mar Ecol 10:97-105

Quammen ML, Onuf CP (1993) Laguna Madre: seagrass changes continue decades after salinity reduction. Estuaries 16:302-310

Reekie EG, Bazzaz FA (1987) Reproductive effort in plants. I. Carbon allocation to reproduction. Am Nat 129:876-896

Saulnier TP, Reekie EG (1995) Effect of reproduction on nitrogen allocation and carbon gain in Oenothera biennis. J Ecol 83:23-29

Short FT (1980) A simulation model of the seagrass production system. In: Phillips RC, McRoy CP (eds) Handbook of seagrass biology: an ecosystem perspective. Garland STPM Press, New York, p 277-295

Spencer D, Anderson L, Ksander G, Klaine S, Bailey F (1994) Vegetative propagule production and allocation of carbon and nitrogen by monoecious Hydrilla verticullata (Lf) Royle grown at two photoperiods. Aquat Bot 48:121-132

Texas Department of Water Resources (1982) The influence of freshwater inflows upon the major bays and estuaries of the Texas Gulf coast. Vol 8. Executive summary (2nd edn). Texas Department of Water Resources, Austin, TX

Tomasko DA, Lapointe BE (1991) Productivity and biomass of Thalassia testudinum as related to water column nutrient availability and epiphyte levels: field observations and experimental studies. Mar Ecol Prog Ser 75:9-17

Tomlinson PB (1969) On the morphology and anatomy of Turtle grass, Thalassia testudinum (Hydrocharitaceae). III. Floral morphology and anatomy. Bull Mar Sci 19:286- 305

Valiela I (1995) Marine ecological processes. Springer, New York

van Tussenbroek BI (1994) Aspects of the reproductive ecology of Thalassia testudinum in Puerto Morelos Reef Lagoon, Mexico. Bot Mar 37:413-419

van Tussenbroek BI (1995) Thalassia testudinum leaf dynamics in a Mexican Caribbean coral reef lagoon. Mar Biol 122:33-40

Vermaat JE, Agawin NSR, Duarte CM, Fortes MD, Marba N, Uri JS (1995) Meadow maintenance, growth and productivity of a mixed Phillipine seagrass bed. Mar Ecol Prog Ser 124:215-225

Wetzel RL, Neckles HA (1986) A model of Zostera marina L. photosynthesis and growth: simulated effects of selected physical-chemical variables and biological interactions. Aquat Bot 26:307-323

Williams K, Koch GW, Mooney HA (1985) The carbon balance of flowers of Diplacus aurantiacus (Scrophulariaceae). Oecologia 66:530-535

Willson MF (1983) Plant reproductive ecology. John Wiley \& Sons, New York

Ziegler S, Benner R (1999) Ecosystem metabolism in a subtropical, seagrass-dominated lagoon. Mar Ecol Prog Ser 180:149-160

Zieman JC (1974) Methods for the study of the growth and production of turtle grass, Thalassia testudinum König. Aquaculture 4:139-143

Zieman JC, Wetzel RG (1980) Productivity in seagrasses: methods and rates. In: Phillips RC, McRoy CP (eds) Handbook of seagrass biology: an ecosystem perspective. Garland STPM Press, New York, p 87-116 